\title{
INDUSTRIAL REVOLUTION AND TECHNOLOGICAL PATTERN: ESSENTIAL CHARACTERISTICS, SIMILARITIES AND DISTINCTIVE FEATURES
}

\author{
Irina S. Averina \\ Volgograd State University, Volgograd, Russian Federation
}

\begin{abstract}
The article analyzes the evolution of the phenomena "technological order" and "industrial revolution", which made it possible to form the author's model for the phenomena under study. As a result of considering these characteristics of the designated economic indicators, groups of features were formulated that characterize the concepts from the point of view of identity, as well as groups of features indicating their main distinctive and specific characteristics. The study of the origin of these terms also influenced the possibility of defining these phenomena from the standpoint of the dynamic nature (origin, formation, development, transformation, adaptation) of each of the components within their stage-by-stage development. The indicated evolutionary character can be traced within the framework of the change of each of the technological orders (the first (17851835), second (1830-1890), third (1880-1940), fourth (1930-1990), fifth (1985-2035), sixth (2010-2060)) and industrial revolutions (First $\left(18^{\text {th }}-19^{\text {th }}\right.$ centuries), Second (second half of the $19^{\text {th }}$ century - early $20^{\text {th }}$ century), Third $(1960-$ the first decade of the $20^{\text {th }}$ century, Fourth (2011 - up to the present time), which predetermines the differential development of national economic systems as a whole.

Key words: industrial revolution, industrial revolution 4.0, technological pattern, scientific and technological progress, economic system, smart technologies, technical and economic development.

Citation. Averina I.S. Industrial Revolution and Technological Pattern: Essential Characteristics, Similarities and Distinctive Features. Vestnik Volgogradskogo gosudarstvennogo universiteta. Ekonomika [Journal of Volgograd State University. Economics], 2021, vol. 23, no. 1, pp. 52-63. (in Russian). DOI: https://doi.org/10.15688/ ek.jvolsu.2021.1.4
\end{abstract}

УДК 330:338.45.01

Дата поступления статьи: 21.12.2020

ББК 65.011

Дата принятия статьи: 11.01.2021

\section{ПРОМЫШЛЕННАЯ РЕВОЛЮЦИЯ И ТЕХНОЛОГИЧЕСКИЙ УКЛАД: СУЩНОСТНЫЕ ХАРАКТЕРИСТИКИ, СХОДСТВА И ОТЛИЧИТЕЛЬНЫЕ ЧЕРТЫ}

\author{
Ирина Сергеевна Аверина \\ Волгоградский государственный университет, г. Волгоград, Российская Федерация
}

\footnotetext{
Аннотация. В статье проведен анализ эволюции феноменов «технологический уклад» и «промышлен$\overrightarrow{\widetilde{V}}$ ная революция», который позволил сформировать авторскую позицию в отношении исследуемых явлений. 尺े В результате рассмотрения этимологии обозначенных экономических категорий были сформулированы j группы признаков, характеризующих понятия с точки зрения свойства идентичности, а также группы признаков, указывающих на их принципиальные отличия и специфические характеристики. Исследование происхождения этих терминов также оказало влияние на возможность определения данных явлений с позиции

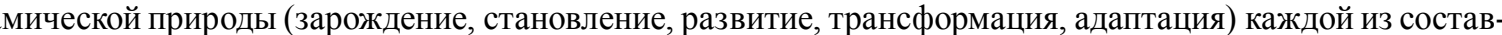
ляющих внутри их поэтапного развития. Обозначенную эволюционность представляется возможным проследить в рамках смены каждого из технологических укладов (первого: 1785-1835 гг.; второго: 1830-1890 гг.;
} 
третьего: 1880-1940 гг; четвертого: 1930-1990 гг; пятого: 1985-2035 гг; шестого: 2010 - 2060 гг.) и промышленных революций (первой: XVIII-XIX вв.; второй: вторая половина XIX в. - начало XX в.; третьей: 1960 г. первое десятилетие XX в.; четвертой: 2011 г. - наст. время), что предопределяет дифференциальность развития национальных хозяйственных систем в целом.

Ключевые слова: промышленная революция, промышленная революция 4.0, технологический уклад, научно-технический прогресс, экономическая система, умные технологии, технико-экономическое развитие.

Цитирование. Аверина И. С. Промышленная революция и технологический уклад: сущностные характеристики, сходства и отличительные черты // Вестник Волгоградского государственного университета. Экономика. - 2021. - Т. 23, № 1. - C. 52-63. - DOI: https://doi.org/10.15688/ek.jvolsu.2021.1.4

\section{Введение}

Развитие общества на современном этапе привело к тому, что изменения в хозяйственной системе происходят с огромной скоростью, а это, несомненно, отражается на жизни общества, в том числе на ее экономической сфере.

Это обстоятельство обусловливает значимость исследований, посвященных анализу подобных изменений. Одними из таких феноменов являются технологические уклады и промышленные революции, которые не только трансформируют жизнь общества, но и обеспечивают смену хозяйственной парадигмы развития в мировом масштабе в целом.

Указанные понятия прочно закрепились в научном экономическом обороте, однако их трактовки с различных точек зрения не дают должного полноценного объяснения соотношения, взаимосвязи, сходства и различий между данными категориями.

Для современного уровня развития экономической теории характерно большое количество научных изысканий (проведенных как отечественными, так и зарубежными исследователями) в области определения содержательных характеристик понятий «технологический уклад» и «промышленная революция». Однако сравнительный анализ данных составляющих не носит системного характера и представлен фрагментарно.

В этой связи приобретают актуальность и значимость исследования, указывающие на отличительные особенности выше обозначенных понятий, их идентичные характеристики, взаимообусловленность, а также взаимозависимость.

Комплексное понимание выделенных аспектов создаст возможности теоретического приращения категориальных знаний в дан- ной области, позволит определить предпосылки смены технологических укладов и промышленных революций в будущем, так как ретроспективный анализ может создать возможности для их прогнозирования.

\section{Эволюция взглядов на феномены «технологический уклад» и «промышленная революция»}

Первоначально термин «технологический уклад» происходит из категории «уклад», которая в общем смысле означает «устройство, установившийся порядок организации чего-нибудь» (хозяйственной жизни, способ организации производства и т. д.). Ключевым в этом обобщенном определении первичного термина «уклад» является «способ организации производства», о котором в технологическом ключе рассуждал К. Маркс, говоря о нем как о явлении, соответствующем определенному уровню развития общества [Маркс и др., 1984].

Однако на данном этапе термин «технологический уклад» еще не вошел в обиход экономической науки, и существующие исследования зависимостей способов производства от уровня технико-технологического развития носили обобщенный характер.

Так, в трудах директора Института экономики (г. Пиза, Италия) Дж. Доси прослеживается понятие «технологическая парадигма», которую он понимал как «модель» или «образец» поддержки избранных технологических проблем на основе законов и принципов естественных наук и материальных технологий [Dosi, 1982].

В трудах зарубежных ученых Б. Карлссона и Р. Станкевич исследуются природа, функции и состав технологических систем, которые отражают структурно-функциональный 
подход к изучению влияния технологий на хозяйственные системы [Carlsson et al., 1991].

Й. Шумпетер под технологическим укладом понимал «совокупность институциональных, экономических, социальных и политических элементов общества», которые были исследованы им в контексте анализа неравномерности развития общества и нововведений [Шумпетер, 1995].

Современное понятие «технологический уклад» получило распространение в отечественной науке благодаря трудам С.Ю. Глазьева и Д.С. Львова в 1980-х гг. ХХ столетия. С.Ю. Глазьев утверждал, что «технологическая структура экономики содержит группы технологических совокупностей, которые связаны друг с другом технологическими цепями одного и того же типа и формируют воспроизводящиеся целостности - технологические уклады» [Глазьев, 1993, с. 72; Львов, 2003].

Также в 1994 г. В.И. Маевским предложено следующее специфическое понимание термина «технологический уклад», которое тесно взаимосвязано с понятием «ядра саморазвития» и базируется на теории циклического развития Н.Д. Кондратьева. В.И. Маевский исследовал принципы внутреннего движения хозяйственной системы, особенности наследственности и изменчивости и утверждал, что существуют тождественные понятия в биологической генетике. При этом «сфера анализа экономической генетики локализована в рамках вещественного саморазвития экономики, то есть процесса, в котором зарождается очередной импульс развития, возникают технологические уклады, отрасли, фирмы» [Маевский, 1994]. Тем самым подчеркивется эволюционная природа технологических изменений хозяйственных систем.

Другой отечественный ученый Ю.В. Яковец трактует понятие «технологический уклад» как совокупность научно-технических направлений, взаимосвязанных ресурсной и технологической базой, выраженных в ядре уклада; генотип некоторого этапа в развитии технологического базиса общества [Яковец, 1996, c. 45].

Обобщая трактовки С.Ю. Глазьева, Д.С. Львова, а также Ю.В. Яковца, можно говорить о технологическом укладе как о «совокупности технологий, характерных для оп- ределенного уровня развития производства в связи с научным и технико-технологическим прогрессом и переходом от более низких укладов к более прогрессивным» [Авербух, 2010, с. 159].

В 1997 г. выходит работа отечественных ученых И.В. Липсица, А.А. Нещадина «Промышленная политика России: принципы формирования и механизмы реализации», в которой дано следующее определение технологического уклада: технологический уклад - это «единое, устойчивое объединение сопряженных производств, в рамках которого происходит обособленный макроэкономический цикл, состоящий из добычи первичных производственных ресурсов, всех стадий их переработки и выпуска соответствующих конечных продуктов» [Липсиц и др., 1997, с. 28].

По определению другого отечественного ученого Р.М. Нижегородцева, «технологический уклад - это целостная система, единый межотраслевой комплекс взаимосвязанных производств, основанных на близких по характеру технико-технологических принципах и решениях» [Возрождение экономики ... , 2000]. Данное определение отражает системный подход к исследованию, прослеживаемый в работах С.Ю. Глазьева и Д.С. Львова, Ю.В. Яковца и других ученых.

Одним из зарубежных ученых Ф. Кастеллаччи, вслед за ранее упомянутым Дж. Доси, рассматривается понятие «технологическая парадигма», которое тесно коррелирует с современными представлениями термина «технологический уклад».

Данный автор трактует технологическую парадигму как интеграцию между отраслевыми инновациями в производстве и услугах, которая указывает на важность межотраслевого обмена знаниями в отраслях [Castellacci, 2008].

В трудах венесуэльской ученой К. Перес понятие «технологический уклад» можно проследить через определение «технико-экономической парадигмы», которая понимается как «комплекс промышленных секторов, соответствующая ему институциональная структура, инфраструктура, финансовая структура, а также социально-экономический климат и специфическая система отношений между трудом и капиталом, сформировавши- 
еся на базе внедренного в фазе депрессии пучка базисных технологических инноваций и опосредующих развитие нового технологического стиля» [Perez, 2009].

Указанные трактовки отражают системный подход к анализу исследуемого феномена. Однако можно выделить и несколько иные толкования.

Так, в работах В.И. Белоусова и А.В. Белоусова технологический уклад понимается как комплекс применяемых инноваций, которые обеспечивают качественный и количественный скачок в процессе развития производственных сил общества [Белоусов и др., 2010].

Целесообразно представить вышеприведенный сравнительный анализ подходов к определению технологического уклада в виде таблицы (табл. 1).
Проанализировав этимологию и эволюцию феномена «технологический уклад», целесообразно перейти к исследованию второго из указанных терминов - «промышленная революция», обобщив последовательность эволюции представлений (табл. 2). Однако первично целесообразно определить этимологию термина «промышленная революция».

Слово «революция» представляет собой коренной переворот в какой-либо сфере хозяйственной жизни (экономической, политической, культурной и т. д.). Также под термином «революция» следует понимать резкий «скачок», прерывающий постепенность изменений, преобразующий сущность, сменяющий основания и системный характер взаимосвязей предмета в целом.

Таблица 1

Сравнительный анализ подходов к определению категории «технологический уклад»

\begin{tabular}{|c|c|c|c|}
\hline $\begin{array}{c}\text { Подходы } \\
\text { к определению }\end{array}$ & Автор концепции & $\begin{array}{c}\text { Основные характеристики термина } \\
\text { «технологический уклад» }\end{array}$ & Временные рамки \\
\hline \multirow{2}{*}{$\begin{array}{l}\text { Общие представле- } \\
\text { ния, послужившие } \\
\text { основой для даль- } \\
\text { нейших исследований } \\
\text { категории }\end{array}$} & К. Маркс & Способ организации производства & $\begin{array}{c}1867 \text { г., } 1885 \text { г., } \\
1894 \text { г. }\end{array}$ \\
\hline & Дж. Доси & $\begin{array}{l}\text { «Технологическая парадигма» как «мо- } \\
\text { дель» или «образец» поддержки из- } \\
\text { бранных технологических проблем на } \\
\text { основе законов и принципов естествен- } \\
\text { ных наук и материальных технологий }\end{array}$ & 1982 г. \\
\hline $\begin{array}{l}\text { Структурно-функцио- } \\
\text { нальный подход }\end{array}$ & $\begin{array}{l}\text { Б. Карлссон, } \\
\text { Р. Станкевич }\end{array}$ & $\begin{array}{l}\text { Природа, функции и состав техноло- } \\
\text { гических систем, их взаимосвязь с хо- } \\
\text { зяйственными системами }\end{array}$ & 1991 г. \\
\hline \multirow[t]{7}{*}{ Системный подход } & С.Ю. Глазьев & \multirow{7}{*}{$\begin{array}{l}\text { Совокупность технологий, характер- } \\
\text { ных для определенного развития про- } \\
\text { изводства, связанного с научно- } \\
\text { техническим прогрессом и развитием } \\
\text { необходимых элементов хозяйственной } \\
\text { системы }\end{array}$} & 1993 г. \\
\hline & Д.С. Львов & & 1993 г. \\
\hline & В.И. Маевский & & 1994 г. \\
\hline & Й. Шумпетер & & 1995 г. \\
\hline & Ю.В. Яковец & & 1996 г. \\
\hline & Р.М. Нижегородцев & & 2000 г. \\
\hline & К. Перес & & 2009 г. \\
\hline $\begin{array}{l}\text { Воспроизводственный } \\
\text { подход }\end{array}$ & $\begin{array}{l}\text { И.В. Липсиц, } \\
\text { А.А. Нещадин }\end{array}$ & $\begin{array}{l}\text { Единое, устойчивое объединение со- } \\
\text { пряженных производств, в рамках ко- } \\
\text { торого происходит обособленный } \\
\text { макроэкономический цикл, состоящий } \\
\text { из добычи первичных производствен- } \\
\text { ных ресурсов, всех стадий их перера- } \\
\text { ботки и выпуска соответствующих ко- } \\
\text { нечных продуктов }\end{array}$ & 1997 г. \\
\hline Факторный подход & В.И. Белоусов & Комплекс применяемых инноваций, & 2010 г. \\
\hline & & $\begin{array}{l}\text { которые обеспечивают скачок в разви- } \\
\text { тии производительных сил общества }\end{array}$ & 2010 г. \\
\hline
\end{tabular}

Примечание. Составлено автором по: [Белоусов и др., 2010; Возрождение экономики ... , 2000; Глазьев, 1993, с. 72; Липсиц и др., 1997, с. 28; Львов, 2003; Маркс, 1984; Шумпетер, 1995; Яковец, 1996, с. 45; Carlsson et al., 1991; Castellacci, 2008; Dosi, 1982; Perez, 2009]. 


\section{Сравнительный анализ подходов \\ к определению категории «промышленная революция»}

\begin{tabular}{|c|c|c|c|}
\hline Подходы к определению & Автор концепции & $\begin{array}{c}\text { Основные характеристики термина } \\
\text { «промышленная революция» }\end{array}$ & Временные рамки \\
\hline \multirow{6}{*}{$\begin{array}{l}\text { Общие представления } \\
\text { и упоминания, послу- } \\
\text { жившие основой к } \\
\text { дальнейшим исследо- } \\
\text { ваниям категории }\end{array}$} & Т. Твисс & $\begin{array}{l}\text { Промышленная революция в Англии } \\
\text { привела к результатам еще более при- } \\
\text { мечательным и важным }\end{array}$ & 1847 г. \\
\hline & $\begin{array}{l}\text { К. Маркс и Ф. Эн- } \\
\text { гельс }\end{array}$ & $\begin{array}{l}\text { Переход от одного технологического } \\
\text { способа производства к другому, от } \\
\text { одного исторического этапа в развитии } \\
\text { техники к другому }\end{array}$ & 1867 г. \\
\hline & А. Тойнби & $\begin{array}{l}\text { Становление термина в научной лите- } \\
\text { ратуре }\end{array}$ & 1887 г. \\
\hline & Г. Гиббинс & $\begin{array}{l}\text { Промышленная революция превратила } \\
\text { Англию в «средоточие всемирной тор- } \\
\text { говли и фабричного капитализма» }\end{array}$ & 1988 г. \\
\hline & У. Каннингем & $\begin{array}{l}\text { Цель промышленной революции - рас- } \\
\text { пространение промышленных улучше- } \\
\text { ний во всем мире }\end{array}$ & 1903 г. \\
\hline & Й. Шумпетер & $\begin{array}{l}\text { Показана взаимосвязь между теорией } \\
\text { длинных волн Н.Д. Кондратьева и фа- } \\
\text { зами подъема и спада, средней про- } \\
\text { должительностью порядка } 50 \text { лет }\end{array}$ & 1911 г. \\
\hline Системный подход & П. Манту & $\begin{array}{l}\text { «Расширение ранее сжатых сил, вне- } \\
\text { запное распускание и пышный рост } \\
\text { зародышей, остававшихся до тех пор } \\
\text { в скрытом или дремлющем состоя- } \\
\text { нии...». Рассматривать ее с техниче- } \\
\text { ской, экономической и социальной } \\
\text { точек зрения }\end{array}$ & 1937 г. \\
\hline \multirow[t]{2}{*}{$\begin{array}{l}\text { Трансформационный } \\
\text { подход }\end{array}$} & Э. Хобсбаум & $\begin{array}{l}\text { Процесс модернизации с позиции те- } \\
\text { зиса двойной революции }\end{array}$ & 1962 г. \\
\hline & В.И. Ленин & $\begin{array}{l}\text { Резкое преобразование «всех обще- } \\
\text { ственных отношений, происходящее } \\
\text { под влиянием машин (машинной ин- } \\
\text { дустрии)» }\end{array}$ & 1967 г. \\
\hline Ресурсный подход & $\begin{array}{l}\text { Р.Б. Вон, Дж. Голд- } \\
\text { стоун, К. Померанц, } \\
\text { Д. Ли, В. Фэн, } \\
\text { А.Г. Франк }\end{array}$ & $\begin{array}{l}\text { Промышленная революция обеспечи- } \\
\text { вает гегемонию, обусловленную «бо- } \\
\text { нусами» в виде удачного расположе- } \\
\text { ния природных ресурсов }\end{array}$ & 1990-2000 гг. \\
\hline $\begin{array}{l}\text { Институциональный } \\
\text { подход }\end{array}$ & $\begin{array}{l}\text { Д. Лэндис, Р. Аллен, } \\
\text { П. Врис }\end{array}$ & $\begin{array}{l}\text { Восприятие промышленных револю- } \\
\text { ций с точки зрения необходимости ин- } \\
\text { ституциональных изменений }\end{array}$ & 1999-2003 гг. \\
\hline
\end{tabular}

Примечание. Составлено автором по: [Булдыгин, 2017, с. 91; Гиббинс, 1899, с. 76-80; Каннингем, 1903, c. 223-224; Кулишер, 2004, с. 493; Манту, 1937, с. 415; Маркс и др., 1955; Погребинская, 2005; Рифкин, 2014, c. 18; Сен-Симон, 1948, с. 5; Шваб, 2018; Hobsbawm, 1962; Landes, 1999; Toynbee, 1887; Vries, 2003 ].

Иными словами, говоря об экономическом аспекте термина «революция», можно утверждать, что она представляет собой коренной перелом в базисе хозяйственной системы, который провоцирует изменения во всех областях жизни общества.

Становление и развитие термина «промышленная революция» с позиции системного и трансформационного подходов прослежи- вается в период с 1847 по 1960-е годы. Дальнейшее развитие термина следует связывать с исследованиями данного феномена применительно уже к каждой из промышленных революций как таковых. Однако конец XX столетия ознаменовался применением ресурсного и институционального подходов к исследованию самого обобщенного восприятия явления промышленных революций вновь. 


\section{Результаты исследования}

Исследовав различные подходы к определению терминов «промышленная революция» и «технологический уклад», необходимо перейти к их сравнению с позиции временных рамок смены каждого из них.

Первоначально рассмотрим изменения технологических укладов, выделяемых на современном этапе развития экономической теории.

В настоящее время выделяется шесть технологических укладов, порожденных различными условиями и факторами развития общества:

- первый (1785-1835 гг.) - основывался на развитии технологий, связанных с текстильной промышленностью, изобретением ткацких и прядильных машин, которые обусловили переход текстильной промышленности на машинную базу;

- второй (1830-1890 гг.) - основан на использовании энергии пара и угля (изобретении паровой машины, парового двигателя, локомобиля), что привело к развитию железнодорожного паровозного транспорта, пароходства, механизации производства;

- третий (1880-1940 гг.) - базируется на использовании в промышленном производстве электрической энергии, развитии тяжелого машиностроения и электротехнической промышленности на основе использования стального проката, новых открытий в области химии;

- четвертый (1930-1990 гг.) - основан на дальнейшем развитии энергетики с использованием нефти и нефтепродуктов, газа, средств связи, новых синтетических материалов;

- пятый (1985-2035 гг.) - опирается на достижения в области микроэлектроники, информатики, биотехнологии, генной инженерии, новых видов энергии, материалов, освоения космического пространства, спутниковой связи и т. п.;

- шестой (2010-2060 гг.) - характеризуется развитием робототехники, биотехнологий, основанных на достижениях молекулярной биологии и генной инженерии, нанотехнологии, систем искусственного интеллекта, глобальных информационных сетей, интегрированных высокоскоростных транспортных систем;
- седьмой (гипотетически прогнозируемый: 2050-2110 гг.) [Авербух, 2010, с. 160] гипотетически будет характеризоваться вакуумной технологией и энергией (когнитивные и вакуумные технологии; взрывное развитие биомедицины; биороботизация; технологии на основе резонанса и различных полей с использованием ноосферы; колонизация планет солнечной системы и выход в дальний космос) [Василенко, 2013, с. 67].

Следует отметить, что ранее автором был проведен анализ взглядов отечественных и зарубежных ученых, позволивший рассмотреть характерные черты каждой промышленной революции [Аверина, 2020]:

- первая промышленная революция (1760-е - 1840-е гг.): аграрный переворот в Англии в XVI в.; вытесненные с земель крестьяне стали дешевой рабочей силой; переход от ручного труда к машинному на основании изобретений [Гиббинс, 1899, с. 76-80; Кулишер, 2004, с. 493; Маркс и др., 1955, с. 256; Сен-Симон, 1948, с. 5];

- вторая промышленная революция (1870-1914 гг.): изобретение электромагнитных роторных устройств стало основой для внедрения электричества в технологии [Погребинская, 2005];

- третья промышленная революция (1960 г. - первое десятилетие XXI в.): применение ядерной энергии в промышленности и необходимость перемещения радиоактивных материалов без участия человека [Рифкин, 2014, c. 18];

- четвертая промышленная революция (2011 г. - наст. время): распространение Интернета, цифровизация, развитие электроники, создание цифровых платформ, внедрение НБИК-технологий (нано-, био-, информационных и когнитивных технологии), облачных вычислений и искусственного интеллекта во все сферы жизни общества [Шваб, 2018].

Для выявления общих черт и различий анализируемых феноменов «технологический уклад》 и «промышленная революция» в их поэтапном развитии следует провести детальный сравнительный анализ.

Неоднородность во временных интервалах анализируемых явлений указывает на тот факт, что зачастую смена технологического уклада не соответствует смене промышлен- 
ной революции (табл. 3). Иными словами, изменения технологий в рамках одного уклада первоначально способствуют постепенным изменениям в определенных областях народного хозяйства, которые, накапливаясь, порождают противоречия в существующем хозяйственном механизме. При этом следующее поколение прорывных инновационных технологий обусловливает явление нового технологического уклада, который «прерывает постепенность изменений» и провоцирует коренной перелом хозяйственной системы в целом в результате накопления внутренних институциональных и экономических противоречий.

Сравнение временных интервалов промышленных революций и технологических укладов показывает, что примерные рамки первой промышленной революции и первого технологического уклада совпадают. Второй и третий технологические уклады, в свою очередь, фактически совпадают по временным рамкам со второй промышленной революцией. Четвертый технологический уклад и частично пятый идентичны во временном контексте третьей промышленной революции. В свою очередь, шестой и прогнозируемый седьмой научные технологические уклады соответствуют рамкам четвертой промышленной революции.

Также обратим внимание на тот факт, что временные рамки начала и конца каждого из технологических укладов и каждой промышленной революции «накладываются» друг на друга. Иными словами, нельзя четко обозначить смену одного этапа другим, так как окончание каждого из них происходит по-

Таблица 3

\section{Смена промышленных революций и технологических укладов: сходства и отличительные черты}

\begin{tabular}{|c|c|c|c|c|}
\hline $\begin{array}{c}\text { Технологический } \\
\text { уклад (ТУ) }\end{array}$ & $\begin{array}{l}\text { Временной } \\
\text { промежуток }\end{array}$ & $\begin{array}{c}\text { Промышленные } \\
\text { революции }\end{array}$ & Сходства & Отличия \\
\hline Первый ТУ & $(1785-1835$ гг.) & $\begin{array}{l}\text { Первая про- } \\
\text { мышленная ре- } \\
\text { волюция }\end{array}$ & $\begin{array}{l}\text { Переход от ручного труда } \\
\text { к машинному }\end{array}$ & $\begin{array}{l}\text { В условиях 1-го ТУ речь } \\
\text { не идет об аграрном пе- } \\
\text { ревороте }\end{array}$ \\
\hline Второй ТУ & $(1870-1890$ гг.) & \multirow[t]{2}{*}{$\begin{array}{l}\text { Вторая про- } \\
\text { мышленная ре- } \\
\text { волюция }\end{array}$} & $\begin{array}{l}\text { Изобретение парового } \\
\text { двигателя, строительство } \\
\text { железных дорог и т. д. }\end{array}$ & Не выявлено \\
\hline Третий ТУ & $(1880-1940$ гг.) & & $\begin{array}{l}\text { Внедрение электричества } \\
\text { в технологии, механиза- } \\
\text { ция производства }\end{array}$ & Не выявлено \\
\hline Четвертый ТУ & (1960-1990 гг.) & \multirow[t]{2}{*}{$\begin{array}{l}\text { Третья про- } \\
\text { мышленная ре- } \\
\text { волюция }\end{array}$} & $\begin{array}{l}\text { Внедрение ядерной энер- } \\
\text { гии в промышленность }\end{array}$ & $\begin{array}{l}\text { Развитие энергетики с } \\
\text { использованием нефти и } \\
\text { нефтепродуктов, газа, } \\
\text { средств связи, новых син- } \\
\text { тетических материалов }\end{array}$ \\
\hline \multirow[t]{2}{*}{ Пятый ТУ } & \multirow[t]{2}{*}{$(1985-2035$ гг.) } & & \multirow{3}{*}{$\begin{array}{l}\text { Внедрение цифровых } \\
\text { технологий в хозяйствен- } \\
\text { ную жизнь общества, } \\
\text { развитие генной инжене- } \\
\text { рии, робототехники, гло- } \\
\text { бальных информацион- } \\
\text { ных сетей молекулярной } \\
\text { биологии, освоение кос- } \\
\text { мического пространства, } \\
\text { спутниковой связи и т. д. }\end{array}$} & \multirow[t]{3}{*}{ Не выявлено } \\
\hline & & \multirow{3}{*}{$\begin{array}{l}\text { Четвертая про- } \\
\text { мышленная ре- } \\
\text { волюция }\end{array}$} & & \\
\hline Шестой ТУ & (2010-2060 гг.) & & & \\
\hline Седьмой ТУ * & $(2050-2110$ гг.) & & $\begin{array}{l}\text { Невозможно спрогнози- } \\
\text { ровать }\end{array}$ & $\begin{array}{l}\text { Невозможно спрогнози- } \\
\text { ровать }\end{array}$ \\
\hline
\end{tabular}

Примечание. Составлено автором по: [Авербух, 2010, с. 160; Булдыгин, 2017, с. 91; Гиббинс, 1899, с. 7680; Кулишер, 2004, с. 493; Маркс и др., 1955, с. 256; Погребинская, 2005; Рифкин, 2014, с. 18; Сен-Симон, 1948 , c. 5 ; Шваб, 2018]. * - невозможно определить, будет ли 7-й технологический уклад соответствовать пятой промышленной революции (в таблице отмечено серой областью). 
степенно и взаимосвязано с началом нового этапа (уклада, революции).

Проанализировав сходства и отличия временных интервалов технологических укладов и промышленных революций, целесообразно проследить идентичность и различия их содержательной части.

Так, первая промышленная революция по своему содержанию и характеру изменений в целом соответствует первому технологическому укладу. Однако в содержательной части этих двух феноменов имеются и отличительные характеристики.

Так, при анализе исследований, посвященных рассмотрению первого технологического уклада, можно выявить, что в его рамках не прослеживается упоминаний об аграрном перевороте, который был спровоцирован изменением технологий, нашедшим свое отражение в результатах первой промышленной революции.

Основными характеристиками первой промышленной революции являются: создание механизированных заводов и фабрик, ускорение процесса урбанизации. При этом основой первого технологического уклада являются: текстильная промышленность, текстильное машиностроение, выплавка чугуна, обработка железа, строительство каналов, водяной двигатель. Рост промышленности приводит к росту городского населения. Сами технологии выступают основой технологического уклада и являются базисом промышленной революции как таковой.

Ядром второго технологического уклада стало изобретение парового двигателя, активное строительство железных дорог, развитие транспорта, машиностроения и пароходостроения, угольной, станкостроительной промышленности и черной металлургии. Так же, как второй технологический уклад, вторая промышленная революция характеризуется строительством железных дорог и других транспортных сетей, использованием телеграфа, стремительным ростом промышленности, вытеснением гужевого транспорта машинами. Однако относящееся ко второй промышленной революции возникновение отраслей электроэнергетики, нефтехимической промышленности, автомобилестроения, сталелитейной промышленности в классифи- кации промышленных укладов относится к третьему из них.

В этой связи можно отметить, что феномены двух технологических укладов (второго и третьего) обусловили явление третьей промышленной революции (этим объясняется совпадение их временных интервалов).

Четвертый технологический уклад о3наменовался дальнейшим развитием автомобилестроения, тракторостроения, становлением цветной металлургии, началом производства синтетических материалов, органической химии, в том числе как продуктов переработки нефти, производством товаров длительного пользования, массовым серийным производством.

Говоря о рамках третьей промышленной революции, совпадающей частично с временным интервалом четвертого технологического уклада, следует отметить, что для нее характерно создание логических контроллеров, их программирование (обусловившее автоматизацию производства), развитие связи, создание сетей персональных компьютеров, появление сотовых телефонов. Последние из этих составляющих относятся уже к пятому технологическому укладу. Этим объясняется, что во временном контексте третья промышленная революция включает временной лаг четвертого и частично пятого технологических укладов.

В целом пятый технологический уклад охарактеризован развитием электронной промышленности, вычислительной и оптоволоконной техники, программного обеспечения, телекоммуникаций, роботостроения, производства и переработки газа, информационных услуг. Данный уклад лишь частично соответствует начальному этапу четвертой промышленной революции, которую обусловливают следующие перспективные инновации: 3d-печать, роботы и т. д. Основой этому укладу служат нанотехнологии.

Следует отметить, что отличительной особенностью четвертой промышленной революции является не стремление к повышению производительности, ее задача заключается в росте продуктивности, гибкости и кастомизации (индивидуализации товаров и услуг в соответствии с желаниями конкретных потребителей). 
В это же время происходит явление шестого технологического уклада, основанного на развитии нанотехнологий в сфере электроники, фотоники, покрытий, оптики, биотехнологии и т. д., который по временным рамкам также совпадает с четвертой промышленной революцией.

Отмеченное несовпадение смены технологических укладов и промышленных революций объясняется несовпадением их темпов.

Эволюция в рамках одного технологического уклада (зарождение, становление, развитие, трансформация и адаптация) не совпадает с данными процессами в рамках промышленной революции. Новый технологический уклад указывает на создание инновационной технологии, изменяющей единый технический уровень сопряженных производств, однако этого недостаточно для коренного революционного перелома хозяйственной системы в целом, а лишь способствует созданию противоречий в системе и их постепенному накоплению. В свою очередь, новая прорывная базисная технология (указывающая на явление нового технологического уклада) усугубляет эти противоречия и окончательно «разрывает» рутинизированные процессы, что обусловливает необходимость базисных трансформаций как в экономической, так и в институциональной системе, а следовательно - и явление революционности.

\section{Выводы}

При помощи анализа этимологии и эволюции терминов «технологический уклад» и «промышленная революция» были определены различные подходы (структурно-функциональный, системный, воспроизводственный, факторный и т. д.) к их изучению, существующие в экономической теории.

На основании анализа содержательных характеристик, присущих различным «этапам» данных феноменов (первого - шестого технологических укладов, первой - четвертой промышленных революций), были выделены их сходства и отличия, в том числе с позиции временного континуума.

Несовпадение временных интервалов между анализируемыми явлениями объясняется тем, что развитие технологий, зачастую «накапливая» свою силу (в содержательном аспекте), порождает промышленные революции, четкие границы периодов которых не могут быть однозначно определены для всех существующих хозяйственных систем в мире, так как каждая способна переживать разные уклады или революции.

Этим обстоятельством объясняется значимость исследований, посвященных данной теме, с позиции межстранового, межрегионального и межорганизационного аспектов.

\section{СПИСОК ЛИТЕРАТУРЫ}

Авербух, В. М. Шестой технологический уклад и перспективы России / В. М. Авербух // Вестник Ставропольского государственного университета. - 2010. - № 71. - С. 159-166.

Аверина, И. С. Эволюция феномена «промышленная революция»: предпосылки и факторы / И. С. Аверина // Вестник Волгоградского государственного университета. Экономика. 2020.-T. 22, №4. -C. 18-25.-DOI: https://doi.org/ 10.15688/ek.jvolsu.2020.4.2.

Белоусов, В. И. Технологические уклады и преодоление экономических кризисов страны, 2010 / В. И. Белоусов, А. В. Белоусов. - Электрон. текстовые дан. - Режим доступа: http://www. perspektivy.info/print.php?ID=47065. - Загл. $\mathrm{c}$ экрана (дата обращения: 20.12.2020).

Булдыгин, С. С. Концепция промышленной революции: от понятия до наших дней / С. С. Булдыгин // Вестник Томского государственного университета. - 2017. - № 420. - С. 91-95.

Василенко, В. Технологические уклады в контексте стремления экономических систем к идеальности / В. Василенко // Социально-экономические проблемы страны. - 2013. - № 1 (8). C. 65-72.

Возрождение экономики России: путь в XXI век : [монография] / В. П. Логинов [и др.]. - М. : Наука, 2000. $-268 \mathrm{c}$.

Гиббинс, Г. Очерк английской торговли и колоний / Г. Гиббинс. - СПб. : Изд. О. Н. Поповой, 1899. $-123 \mathrm{c}$.

Глазьев, С. Ю. Теория долгосрочного технико-экономического развития / С. Ю. Глазьев. - М. : ВлаДар, 1993. - 310 c.

Каннингем, У. Западная цивилизация с экономической точки зрения / У. Каннингем. - М. : А.И. Мамонтов, 1903. -274 с.

Кулишер, И. М. История экономического быта Западной Европы : в 2 т. / И. М. Кулишер. - Челябинск : Социум, 2004. - Т. 2. -1030 с. 
Липсиц, И. В. Промышленная политика России: принципы формирования и механизмы реализации / И. В. Липсиц, А. А. Нещадин // Общество и экономика. - 1997. - № 6.

Львов, Д. С. Перспективы долгосрочного социальноэкономического развития России / Д. С. Львов // Вестник российской академии наук. - 2003. Т. 73, № 8. - С. 675-697.

Маевский, В. И. Экономическая эволюция и экономическая генетика / В. И. Маевский // Вопросы экономики. - 1994. - № 5. - С. 4-21.

Манту, П. Промышленная революция XVIII столетия в Англии : (опыт исследования) / П. Манту. - М. : Соцэкгиз, 1937. -440 с.

Маркс, К. О диалектическом и историческом материализме : [сборник] / К. Маркс, Ф. Энгельс, В. И. Ленин. - М. : Политиздат, 1984. - 636 с.

Маркс, К. Собрание сочинений / К. Маркс, Ф. Энгельс. -М. : Изд-вополит. лит., 1955.-Т. 2. -652 с.

Погребинская, В. А. Вторая промышленная революция / В. А. Погребинская // Экономический журнал. - 2005. - № 10. - Электрон. текстовые дан. - Режим доступа: http:// economicarggu.ru/2005_1/index.shtml (дата обращения: 16.11.2020). - Загл. с экрана.

Рифкин, Дж. Третья промышленная революция: Как горизонтальные взаимодействия меняют энергетику, экономику и мир в целом : пер. с англ. / Дж. Рифкин. - М. : Альпина нон-фикшн, 2014. -410 c.

Сен-Симон, А. О промышленной системе / СенА. Симон // Избранные сочинения : в 2 т. М. : Изд-во Акад. наук СССР, 1948. - Т. 2.

Шваб, К. Технологии четвертой промышленной революции / К. Шваб, Н. Дэвис. - М. : Эксмо, 2018. -320 c.

Шумпетер, Й. Капитализм, социализм и демократия : пер. с англ. / Й. Шумпетер. - М. : Экономика, 1995. - $540 \mathrm{c}$.

Яковец, Ю. В. Экономика России: перемены и перспективы/ Ю. В. Яковец. - М. : Мысль, 1996. -280 с.

Carlsson, B. On the nature, function and composition of technological systems / B. Carlsson, R. Stankiewicz // Evolutionary Economics. 1991. - Vol. 2, № 1. - P. 93-118.

Castellacci, F. Technological paradigms, regimes and trajectories: Manufacturing and service industries in a new taxonomy of sectoral pattern of innovation /F. Castellacci // Research Policy. - 2008. - № 37.Electronic text data. - Mode of access: https:// econpapers.repec.org/article/eeerespol/v 3a37_3ay_3a2008_3ai_3a6-7_3ap_3a978-994.htm.Title from screen (date of access: 20.12.2020).

Dosi, G. Technological paradigm and technological trajectories / G. Dosi // Research Policy. - 1982. № 11.
Hobsbawm, E. The Age of Revolution / E. Hobsbawm. L. : Weidenfeld \& Nicolson, 1962. - 366 p.

Landes, D. S. The Wealth and Poverty of Nations: Why Some Are So Rich and Some So Poor /D. S. Landes. -New York: W.W. Norton, 1999. $658 \mathrm{p}$.

Perez, C. Techno-Economic Paradigms: Essays in Honour / C. Perez. - Anthem Press, 2009. - 395 p.

Toynbee, A. Lectures on the Industrial Revolution in England / A. Toynbee. - London, Rivington's, 1887. $-256 \mathrm{p}$.

Vries, P. Via Peking Back to Manchester: Britain, the Industrial Revolution, and China / P. Vries. Leiden : CNWS Publications, 2003.-109p.

\section{REFERENCES}

Averbuh V.M. Shestoj tekhnologicheskij uklad i perspektivy Rossii [The Sixth Technological Order and Prospects for Russia]. Vestnik Stavropol'skogo gosudarstvennogo universiteta [Bulletin of the Stavropol State University], 2010, no. 71, pp. 159-166.

Averina I.S. Evolyuciya fenomena «promyshlennaya revolyuciya»: predposylki i factory [Evolution of the "Industrial Revolution" Phenomenon: Prerequisites and Factors]. Vestnik Volgogradskogo gosudarstvennogo universiteta. Ekonomika [Journal of Volgograd State University. Economics], 2020, vol. 22, no. 4, pp. 18-25. DOI: https://doi.org/10.15688/ek.jvolsu.2020.4.2.

Belousov V.I., Belousov A.V. Tekhnologicheskie uklady i preodolenie ekonomicheskih krizisov strany [Technological Structures and Overcoming the Country's Economic Crises]. 2010. URL: http://www.perspektivy.info/print. php?ID=47065 (accessed 20 December 2020).

Buldygin S.S. Koncepciya promyshlennoj revolyucii: ot ponyatiya do nashih dnej [The Concept of the Industrial Revolution: From the Concept to the Present Day]. Vestnik Tomskogo gosudarstvennogo universiteta [Bulletin of the Tomsk State University], 2017, no. 420, pp. 91-95.

Vasilenko V. Tekhnologicheskie uklady v kontekste stremleniya ekonomicheskih sistem k ideal'nosti [Technological Structures in the Context of Economic Systems Striving for Ideality]. Social'no-ekonomicheskie problemy strany [Socio-Economic Problems of the Country], 2013, no. 1 (8), pp. 65-72.

Loginov V.P., Kurnysheva I.R., Sokolov Yu.I. et al. Vozrozhdenie ekonomiki Rossii: put'v XXI vek: [monografiya] [Revival of the Russian Economy: Way to the $21^{\text {st }}$ Century. Monograph]. Moscow, Nauka Publ., 2000. 268 p. 
Gibbins G. Ocherk anglijskoj torgovli i kolonij [Essay on English Trade and Colonies]. SPb., Ed. O. N. Popova, 1899. 123 p.

Glaz'ev S.Yu. Teoriya dolgosrochnogo tekhnikoekonomicheskogo razvitiya [The Theory of Long-Term Technical and Economic Development]. Moscow, VlaDar Publ., 1993. $310 \mathrm{p}$.

Kanningem U. Zapadnaya civilizaciya $s$ ekonomicheskoj tochki zreniya [Western Civilization From an Economic Point of View]. Moscow, A.I. Mamontov Publ., 1903. 274 p.

Kulisher I.M. Istoriya ekonomicheskogo byta Zapadnoj Evropy: $v 2$ t. [The History of the Economic Life of Western Europe. In 2 Vols.]. Chelyabinsk, Sotsium Publ., 2004, vol. 2. 1030 p.

Lipsic I.V., Neshchadin A.A. Promyshlennaya politika Rossii: principy formirovaniya i mekhanizmy realizacii [Industrial Policy of Russia: Principles of Formation and Mechanisms of Implementation]. Obshchestvo i ekonomika, 1997, no. 6.

L'vov D.S. Perspektivy dolgosrochnogo Social'noekonomicheskogo razvitiya Rossii [Prospects for Long-Term Socio-Economic Development of Russia]. Vestnik rossijskoj akademii nauk [Bulletin of the Russian Academy of Sciences], 2003, vol. 73, no. 8, pp. 675-697.

Maevskij V.I. Ekonomicheskaya evolyuciya i ekonomicheskaya genetika [Economic Evolution and Economic Genetics]. Voprosy ekonomiki, 1994, no. 5, pp. 4-21.

Mantu P. Promyshlennaya revolyuciya XVIII stoletiya $v$ Anglii: (opyt issledovaniya) [Industrial Revolution of the $18^{\text {th }}$ Century in England: (Experience Research)]. Moscow, Sotsekgiz, 1937.440p.

Marks K., Engel's F., Lenin V.I. O dialekticheskom $i$ istoricheskom materializme: [sbornik] [About Dialectical and Historical Materialism. Collection]. Moscow, Politizdat, 1984. 636 p.

Marks K., Engel's F. Sobranie sochinenij [Collected Works]. Moscow, Izd-vo politicheskoy literatury, 1955, vol. 2. $652 \mathrm{p}$.

Pogrebinskaya V.A. Vtoraya promyshlennaya revolyuciya [Second Industrial Revolution]. Ekonomicheskij zhurnal [Economic Journal], 2005, no. 10. URL: http://economicarggu.ru/2005 1/index.shtml (accessed 16 November 2020).
Rifkin Dzh. Tret'ya promyshlennaya revolyuciya: Kak gorizontal'nye vzaimodejstviya menyayut energetiku, ekonomiku i mir v celom: per. $s$ angl. [Industrial Revolution 3: How Horizontal Interactions Are Changing Energy, Economy and the World. Translated from English]. Moscow, Alpina non-fikshn Publ., 2014. 410 p.

Sen-Simon A. O promyshlennoj sisteme [About the Industrial System]. Izbrannye sochineniya: $v 2 t$. [Selected Works. In 2 Vols.]. Moscow, Izd-vo Akademii nauk SSSR, 1948, vol. 2.

Shvab K., Devis N. Tekhnologii chetvertoj promyshlennoj revolyucii [Technologies of the Fourth Industrial Revolution]. Moscow, Eksmo Publ., 2018. 320 p.

Shumpeter J. Kapitalizm, socializm i demokratiya: per. s angl. [Capitalism, Socialism and Democracy. Translated from English]. Moscow, Ekonomika Publ., 1995. 540 p.

Yakovec Yu.V. Ekonomika Rossii: peremeny $i$ perspektivy [Russian Economy: Changes and Prospects]. Moscow, Mysl Publ., 1996. 280 p.

Carlsson B., Stankiewicz R. On the Nature, Function and Composition of Technological Systems. Evolutionary Economics, 1991, vol. 2, no. 1, pp. 93-118.

Castellacci F. Technological Paradigms, Regimes and Trajectories: Manufacturing and Service Industries in a New Taxonomy of Sectoral Pattern of Innovation. Research Policy, 2008, no. 37. URL: https://econpapers.repec.org/article/ eeerespol/v_3a37_3ay_3a2008_3ai_3a6-7_3ap 3a978-994.htm (accessed 20 December 2020).

Dosi G. Technological Paradigm and Technological Trajectories. Research Policy, 1982, no. 11.

Hobsbawm E. The Age of Revolution. London, Weidenfeld \& Nicolson, 1962. 366 p.

Landes D.S. The Wealth and Poverty of Nations: Why Some Are so Rich and Some so Poor. New York, W.W. Norton, 1999. $658 \mathrm{p}$.

Perez C. Techno-Economic Paradigms: Essays in Honour. Anthem Press, 2009. 395 p.

Toynbee A. Lectures on the Industrial Revolution in England. London, Rivington's, 1887. 256 p.

Vries P. Via Peking Back to Manchester: Britain, the Industrial Revolution, and China. Leiden, CNWS Publications, 2003. 109 p. 


\section{Information About the Author}

Irina S. Averina, Candidate of Sciences (Economics), Associate Professor, Department of Economic Theory, World and Regional Economics, Volgograd State University, Prosp. Universitetsky, 100, 400062 Volgograd, Russian Federation, AverinaIS@volsu.ru, https://orcid.org/0000-0002-1100-3421

\section{Информация об авторе}

Ирина Сергеевна Аверина, кандидат экономических наук, доцент кафедры экономической теории, мировой и региональной экономики, Волгоградский государственный университет, просп. Университетский, 100, 400062 г. Волгоград, Российская Федерация, AverinaIS@volsu.ru, https://orcid.org/0000-0002-1100-3421 